\title{
Ameliorating Effect of Cucumis sativus (Cucumbers) against Arsenic Induced Toxicity in Mice
}

\author{
Naaz Fatima1, Nahid Fatmi' ${ }^{1}$, M. Z. Shahzada', Shivdhar Sharma1, \\ Ranjit Kumar', Mohammad Ali², Arun Kumar ${ }^{2 *}$ \\ ${ }^{1}$ Department of Biochemistry, Magadh University, Bodh Gaya, Bihar, India \\ ${ }^{2}$ Mahavir Cancer Institute \& Research Centre, Phulwarisharif, Patna (Bihar), India \\ Email: *arunk31@rediffmail.com
}

How to cite this paper: Fatima, N., Fatmi, N., Shahzada, M.Z., Sharma, S., Kumar, R., Ali, M. and Kumar, A. (2018) Ameliorating Effect of Cucumis sativus (Cucumbers) against Arsenic Induced Toxicity in Mice. Open Journal of Pathology, 8, 78-84. https://doi.org/10.4236/ojpathology.2018.83009

Received: May 17, 2018

Accepted: July 6, 2018

Published: July 9, 2018

Copyright $\odot 2018$ by authors and Scientific Research Publishing Inc. This work is licensed under the Creative Commons Attribution International License (CC BY 4.0).

http://creativecommons.org/licenses/by/4.0/

\begin{abstract}
In the entire world, about 200 million populations are exposed to arsenic poisoning in groundwater. Arsenic is a very poisonous metalloid and has three allotropic forms. The toxic inorganic arsenic is converted and utilized metabolically into organic form. It is primarily eliminated out from the human body through metabolic wastes like urine and is also deposited in the hair, nails and skin of the affected ones. Arsenic is known to be a carcinogen as Carcinogen category 1 in the forms of arsenic trioxide, arsenic pentoxide, arsenous acids, arsenic acid and their salts. The arsenic also affects the epidermal system, the nervous system and the vascular system of humans. In the present investigation for toxicological evaluation of arsenic Liver Function Tests \& Kidney Function Tests have been considered. It is presumed that medicinal plants have significance in the present day in view of the lethal diseases like AIDS, cancer, hepatitis, nephritis sterility too for which no effective drugs are found till today in modern system of medicine. Medicinal plant based drugs generally have no side effects or the least side effect. Thus to evaluate an ameliorating effect, if any, to mitigate the arsenic toxicity in mice, for which Cucumis sativus (cucumbers) has been taken as curative measure. Sodium arsenite at the dose of $3 \mathrm{mg} / \mathrm{kg}$ body weight was administered for 4 weeks followed by the administration of Cucumis sativus (cucumbers) for 4 and 6 weeks at dose of $500 \mathrm{mg} / \mathrm{kg}$ body weight. Their biochemical levels like liver and kidney function tests were assayed and were found with elevated levels. But, after administration of aqueous extract of Cucumis sativus (cucumbers), there was significant amelioration in the biochemical levels. The protective effect of Cucumis sativus (cucumbers) was shown in the form of normalization of enzymatic and non-enzymatic activities represented by normalization
\end{abstract}


of liver and kidney functions.

\section{Keywords}

Arsenic, Hepatotoxicity, Renal Toxicity, Cucumis sativus (Cucumbers)

\section{Introduction}

Arsenic is a systemic poison, and chronic ingestion of arsenic can lead to a wide range of health problems, which are collectively called arsenicosis or chronic arsenic poisoning. The effects include skin lesions, cancer of the skin, lung a bladder, and gastro-intestinal and pulmonary condition. In the recent times it has caused serious health issues in the population worldwide. Arsenic toxicity through groundwater arsenic contamination is the world's biggest natural groundwater calamities which got a huge impact on global public health. India is facing the consequences of arsenic poisoning mainly in the area of Ganga Brahmaputra fluvial plains. Arsenic is considered to be major environmental health disaster [1] [2] [3]. It is estimated that more than 200 million people are exposed to high level $\left(<10 \mu \mathrm{g} \mathrm{L}^{-1}\right)$ of arsenic toxicity through drinking water [4].

Liver is the organ which not only carries out the metabolic functions but also detoxifies the toxins. In arsenic exposure, arsenate is actively transported into cells by phosphate transporters in liver [5]. Kidneys accumulate arsenic in the presence of repeated exposures. The kidneys are the major route of arsenic excretion, as well as major site of conversion of pentavalent arsenic into the more toxic and less soluble trivalent arsenic. Sites of arsenic damage in the kidney include capillaries, tubules, and glomeruli [6].

In various studies it has been observed that cucurbitacins present in C. sativus exhibited cytotoxicity and anti-cancer activity. Besides this, cucurbitacins also exhibited wide ranges of in-vitro or even in-vivo pharmacological effects and in used as purgative, anti-inflammatory and anti-fertility agent [7].

In the present study, cytoprotective effect of seeds of Cucumis sativus $(\mathrm{Cu}-$ cumber) was done on sodium arsenite induced liver and kidney injury through biochemical assay. No such study on the antidote effect of $C$. sativus on arsenic has been carried out till date. Therefore, the present study is designed to evaluate ameliorating effect of Cucumis sativus (cucumbers) to mitigate the arsenic toxicity in mice.

\section{Materials and Methods}

Animals: Swiss albino mice (Mus musculus), weighing $30 \mathrm{~g}$ to $35 \mathrm{~g}$ of 8 weeks old, were obtained from animal house of Mahavir Cancer Institute and Research Centre, Patna, India (CPCSEA Regd-No. 1129/bc/07/CPCSEA). The research work was approved by the IAEC (Institutional Animal Ethics Committee) with IAEC No. 2015/3E-16/12/15. Food and water to mice were provided ad libitum 
(prepared mixed formulated food by the laboratory itself). The experimental animals were housed in conventional polypropylene cages in small groups (2 each). The rats were randomly assigned to control and treatment groups. The temperature in the experimental animal room was maintained at $22^{\circ} \mathrm{C} \pm 2{ }^{\circ} \mathrm{C}$ with $12 \mathrm{~h}$ light/dark cycle.

Chemicals: Chemicals: Sodium Arsenite (98.5\%) manufactured by Sigma-Aldrich, USA (CAS Number: 7784-46-5), was obtained from the Scientific store of Patna of Bihar India.

Medicinal plant used: Seed extract of Cucumis sativus (cucumbers) was used as antidote.

Preparation of Cucumis sativus (cucumbers) aqueous extract: In the present study, seed of Cucumis sativus (cucumbers) were procured locally from Patna, Bihar, India The identity of the medicinal plant was confirmed by Dr.Ashok Ghosh (Botanist), Department of Botany, Magadh University, Bihar, India. The collected seed of Cucumis sativus (cucumbers) were dried and were grinded to fine powder. The aqueous extract dose was calculated after $\mathrm{LD}_{50}$ estimation which was found to be $4000 \mathrm{mg} \mathrm{kg}^{-1}$ body weight and the final dose $\left(1 / 8^{\text {th }}\right.$ dose) was fixed to $500 \mathrm{mg} \mathrm{kg}^{-1}$ body weight as maximum permissible dose (MPD).

Chronic Toxicity Study: Selected pathogen-free mice were sorted and sodium arsenite was administered at the dose of $3 \mathrm{mg} / \mathrm{kg}$ body weight dose for 4 weeks by Gavage method. Sacrifices were done at the end of $4^{\text {th }}$ week of Sodium arsenite administration in each group.

Bioremediation: Sodium arsenite administration $3 \mathrm{mg} / \mathrm{kg}$ body weight for 4 weeks was followed by the administration of seed of Cucumis sativus (cucumbers) for 6 weeks at the dose of $500 \mathrm{mg} / \mathrm{kg}$ body weight. Animals were sacrificed on $6^{\text {th }}$ weeks of administration.

Biochemical Assessment: Blood samples were collected by orbital puncture and centrifuged to separate the serum to carry out biochemical analysis. Biochemical analysis were performed through serum by standard kit process (Coral crest) through U.V Vis spectrophotometer. The Liver Function Tests (LFT) tests like Serum Glutamate Pyruvate Transaminase (SGPT), Serum Glutamate Oxalate Transaminase (SGOT), Alkaline Phosphatase (ALP) and Bilirubin tests were carried out while in Kidney Function Tests (KFT) Urea, Uric Acid and Creatinine tests were carried out.

Statistical Analysis: Results are presented as mean \pm S.D and total variation present in a set of data was analysed through one-way analysis of variance (ANOVA). Difference among means has been analysed by applying Dunnett's " $\mathrm{t}$ " test at $99.9 \%(\mathrm{p}<0.05)$ confidence level. Calculations were performed with the GraphPad Prism Program (GraphPad Software, Inc., San Diego, USA).

\section{Results}

In the present study Cucumis sativus (cucumbers) seed extract treatment after 
$6^{\text {th }}$ weeks showed a significant change in the Biochemical parameter. Following the Cucumis sativus (cucumbers) treatments, after 6 weeks the SGPT, SGOT, ALP and Bilirubin concentrations in the arsenic-treated mice decreased from $209.7 \pm 6.74 \mathrm{U} / \mathrm{ml}$ to $54.00 \pm 2.18 \mathrm{U} / \mathrm{ml}$ in SGPT level, from $128.7 \pm 2.60 \mathrm{U} / \mathrm{ml}$ to $36.33 \pm 1.32 \mathrm{U} / \mathrm{ml}$ in SGOT level, from $29.67 \pm 1.76 \mathrm{~K}$.A. Unit to $11.07 \pm 0.49$ K.A. Unit in ALP level, from $1.677 \pm 0.06 \mathrm{mg} / \mathrm{dl}$ to $0.9100 \pm 0.04 \mathrm{mg} / \mathrm{dl}$ in bilirubin levels respectively, compared with the post-arsenic values (Table 1).

Following the Cucumis sativus (cucumbers) treatments, after 6 weeks the Urea, Uric acid, and creatinine concentrations in the arsenic-treated mice decreased from $86.67 \pm 2.96 \mathrm{mg} / \mathrm{dl}$ to $39.07 \pm 1.02 \mathrm{mg} / \mathrm{dl}$ in Urea level, from 9.733 $\pm 0.23 \mathrm{mg} / \mathrm{dl}$ to $7.230 \pm 0.09 \mathrm{mg} / \mathrm{dl}$ in Uric acid level, from $3.733 \pm 0.23 \mathrm{mg} \%$ to $1.95 \pm 0.14 \mathrm{mg} \%$ in creatinine levels respectively, compared with the post-arsenic values (Table 2).

\section{Discussion}

In the present study, cytoprotective effect of seeds of Cucumis sativus (Cucumber) was observed on sodium arsenite induced liver and kidney injury through biochemical assay and histopathological study is an exclusively new work added in the field of toxicology. The findings show restoration in parameters of liver function tests and kidney function tests, as compared to sodium arsenite induced toxicity. The biochemical assay showed decrease in the levels of SGPT, SGOT, ALP, bilirubin, urea, uric acid and creatinine. This denotes that Cucumis

Table 1. Changes in Liver Function Test of mice exposed to Sodium arsenite at the dose of $3 \mathrm{mg} / \mathrm{Kg}$ body weight daily for 6 weeks and its amelioration by Cucumis sativus (cucumbers) for 6 weeks.

\begin{tabular}{cccc}
\hline $\begin{array}{c}\text { Biochemical } \\
\text { Parameters }\end{array}$ & $\begin{array}{c}\text { Control } \\
(\mathrm{n}=6)\end{array}$ & $\begin{array}{c}\text { Arsenic four weeks } \\
(\mathrm{n}=6)\end{array}$ & $\begin{array}{c}\text { Cucumis sativus } \\
\text { Six weeks }(\mathrm{n}=6)\end{array}$ \\
\hline SGPT (U/ml) & $25.67 \pm 1.20$ & $209.7 \pm 6.74$ & $54.00 \pm 2.18$ \\
SGOT (U/ml) & $22.00 \pm 2.64$ & $128.7 \pm 2.60$ & $36.33 \pm 1.32$ \\
ALP (K.A Units) & $6.567 \pm 0.35$ & $29.67 \pm 1.76$ & $11.07 \pm 0.49$ \\
Bilirubin (mg/dl) & $0.5633 \pm 0.029$ & $1.677 \pm 0.06$ & $0.9100 \pm 0.04$ \\
\hline
\end{tabular}

The data are presented as mean \pm S.D, $n=6$, significance at $\mathrm{p}<0.0001$.

Table 2. Changes in Kidney Function Test of mice exposed to Sodium arsenite at the dose of $3 \mathrm{mg} / \mathrm{Kg}$ body weight daily for 6 weeks and its amelioration by Cucumis sativus (cucumbers) for 6 weeks.

\begin{tabular}{cccc}
\hline $\begin{array}{c}\text { Biochemical } \\
\text { Parameters }\end{array}$ & $\begin{array}{c}\text { Control } \\
(\mathrm{n}=6)\end{array}$ & $\begin{array}{c}\text { Arsenic four weeks } \\
(\mathrm{n}=6)\end{array}$ & $\begin{array}{c}\text { Cucumis sativus } \\
\text { Six weeks }(\mathrm{n}=6)\end{array}$ \\
\hline Urea $(\mathrm{mg} / \mathrm{dl})$ & $17.33 \pm 2.02$ & $86.67 \pm 2.96$ & $39.07 \pm 1.02$ \\
Uric acid $(\mathrm{mg} / \mathrm{dl})$ & $4.800 \pm 0.45$ & $9.733 \pm 0.23$ & $7.230 \pm 0.09$ \\
Creatinine $(\mathrm{mg} \%)$ & $0.5167 \pm 0.03$ & $3.733 \pm 0.23$ & $1.95 \pm 0.14$ \\
\hline
\end{tabular}

The data are presented as mean \pm S.D, $n=6$, significance at $\mathrm{p}<0.0001$. 
sativus played vital role to combat the side effects of sodium arsenite.

The seeds of cucumber are rich by the number of constituents including crude proteins $(42 \%)$ and fats $(42.5 \%)$. The ash is rich with phosphate $\left(\mathrm{P}_{2} \mathrm{O}_{5}, 0.62 \%\right)$. The extracted oil from seeds is clear and light yellow with specific gravity of 0.91 ; acid value 0.22; sopanification value 1930; soluble fatty acid (as butyric acid) $0.4 \%$ and unsopanification matter $(0.91 \%)$. The fatty acid components are palmitic (0.63\%), stearic (16.2\%), linoleic (40.11) and oleic acid (38.70) [8]. It contains a number of sterols such as codisterol, 25 (27)-dehydroporifersterol, clerosterol, isofucosterol, stigmasterol, campesterol, 22-dihydrobrassicasterol, sitosterol, 25 (27)-dehydrofungisterol, 25 (27)-hydrocondrillasterol, 24- $\beta$-ethyl-25 (27)-dehydrofungisterol, avenasterol, 22-dihydrispinosterol and 24-methylenecolesterol [9]. The gibberellin hormone is also found in seeds. Seed cake contains water $(1.13 \%)$ protein $(72.53 \%)$ ash $(9.7 \%)$, crude fiber $(1 \%)$ and carbohydrates (8.64\%).

In various studies it has been observed that Cucumber extract showed antioxidant activities against various assays including DPPH reduction assay, total oxyradical scavenging capacity (TOSC) assay, trolox equivalent antioxidant capacity (TEAC), total radical-trapping antioxidant parameter (TRAP) or ferric reducing-antioxidant power (FRAP) assays [10] [11] [12]. Melo et al. [13] reported the polyphenol contents in cucumber. Total phenolic contents, flavonols and proanthocyanidins were found to be $9.05 \pm 0.83,2.06 \pm 0.09$ and $55.66 \pm$ $1.52 \mathrm{mg} / 100 \mathrm{~g}$ respectively in cucumber extract. The whole extract contains high concentrations of ascorbic acid (1.49 $\pm 0.85 \mathrm{mg} / 100 \mathrm{~g})$ also (Melo et al. 2006). Like one more study, free phenolics content in cucumber was found to be 14.37 $\pm 1.48 \mathrm{mg} / 100 \mathrm{~g}$ of sample $(73.8 \%)$, when it was examined along with another 10 vegetables [14]. In this experiment bound phenolic compounds as Bound-E and Bound-W were found to be $2.92 \pm 0.07$ (15\%) and $2.17 \pm 0.06(11.2 \%) \mathrm{mg} / 100 \mathrm{~g}$ of sample respectively with high percentages of vitamin C (23.5\%).

Other effects of Cucurbitaceae plants of Indian origin including C. sativus have been well studied for blood sugar lowering potential at dose of $250 \mathrm{mg} / \mathrm{kg}$ by oral administration, it was found that the fruit does not affect the blood sugar level or depress the peak value, after glucose load [15], whereas another study suggested that $C$. sativus decreases significantly the area under the glucose tolerance curve and the hyperglycemic peak on 27 healthy rabbits [16]. The oral administration of the pectin extracted from the fruit of $C$. sativus at a dose of $5 \mathrm{~g} / \mathrm{kg}$ body weight/day showed significant hypolipidemic action in normal as well as cholesterol-fed experimental animals [17]. Allen [18] studied that lectin from the exudates of the fruit of the cucumber having an anti-parasitic function that strongly inhibited by chitin oligosaccharides.

The seeds are useful for quitting burning sensation, constipation, tonic and intermittent fevers [19]. Gill et al. [20] suggested that the methanolic extract of C. sativus seeds possessed significant ulcer potential which could be due to the antioxidant activity at a dose of $300 \mathrm{mg} / \mathrm{kg}$ in pyloric ligation and water immer- 
sion stress induced rat models. The induction effect of UV-B on the antioxidant enzymes such as superoxide dismutase (SOD), guaiacol peroxidase (POD), ascorbic acid peroxidase (APX) and glutathione reductase (GR) and its suppressed modulation to detoxify excess ROS via external application of a-tocopherol and benzoquinone in cucumber cotyledons have also been examined [21]. Boiled leaves with cumin seeds are useful for throat infection. Powdered leaf with sugar acts as a diuretic and it is also given to treat remitted and inflammatory fevers [22].

Therefore, the Cucumis sativus possesses ameliorative effect against arsenic induced toxicity in mice protecting the liver from its deleterious effects.

\section{Conclusion}

Thus, it is evident from entire study that Cucumis sativus plays a very effective and vital role in controlling deleterious effect caused by sodium arsenite by normalizing the biochemical parameters of liver and kidney.

\section{Acknowledgements}

The authors are thankful to Mahavir Cancer Institute and Research Centre for providing infrastructural facility during this work.

\section{References}

[1] Bhattacharya, P., Welch, A.H., Stollenwerk, K.G., McLaughlin, M.J., Bundschuh, J. and Panaullah, G. (2007) Arsenic in the Environment: Biology and Chemistry. Science of the Total Environment, 379, 109-120. https://doi.org/10.1016/j.scitotenv.2007.02.037

[2] Chakraborti, D., Sengupta, M.K., Rahaman, M.M., Ahamed, S., Chowdhury, U.K. and Hossain, M.A. (2004) Groundwater Arsenic Contamination and Its Health Effects in the Ganga-Megna-Brahmaputra Plain. Journal of Environmental Monitoring, 6, 74-83.

[3] Kapaj, S., Peterson, H., Liber, K. and Bhattacharya, P. (2006) Human Health Effects from Chronic Arsenic Poisoning-A Review. Journal of Environmental Science Health Part A, Environmental Science Engineering Toxic Hazard Substance Control, 41, 2399-2428. https://doi.org/10.1080/10934520600873571

[4] Argos, M., Ahsan, H. and Graziano, J.H. (2012) Arsenic and Human Health: Epidemiologic Progress and Public Health Implications. Reviews on Environmental Health, 27, 191-195. https://doi.org/10.1515/reveh-2012-0021

[5] Shi, H., Shi, X. and Liu, K.J. (2004) Oxidative Mechanism of Arsenic Toxicity and Carcinogenesis. Molecular and Cellular Biochemistry, 255, 67-78. https://doi.org/10.1023/B:MCBI.0000007262.26044.e8

[6] Gaim, K., Gebru, G. and Abba, S. (2015) The Effect of Arsenic on Liver Tissue of Experimental Animals (Fishes and Mice)-A Review article. International Journal of Scientific and Research Publications, 5, 1-9.

[7] Guha, J. and Sen, S.P. (1975) The Cucurbitacins: A Review Plant. Biochemistry, 2, 12-28.

[8] Kapoor, L.D. (1990) CRC Handbook of Ayurvedic Medicinal Plants. CRC Press LLC, Boca Raton. 
[9] Garg, V.K. and Nes, W.R. (1986) Occurrence of $\Delta 5$-Sterols in Plants Producing Predominantly $\Delta 7$-Sterols: Studies on the Sterol Compositions of Six Cucurbitaceae seeds. Phytochemistry, 25, 2591-2597. https://doi.org/10.1016/S0031-9422(00)84516-1

[10] Miller, H.E., Rigelhof, F., Marquart, L., Prakash, A. and Kanter, M. (2000) Antioxidant Content of Whole Grain Breakfast Cereals, Fruits and Vegetables. Journal of the American College of Nutrition, 19, 312S-319S. https://doi.org/10.1080/07315724.2000.10718966

[11] Pellegrini, N., Serafini, M., Colombi, B., Del Rio, D., Salvatore, S. and Bianchi, M. (2003) Total Antioxidant Capacity of Plant Foods, Beverages and Oils Consumed in Italy Assessed by Three Different in Vitro Assays. The Journal of Nutrition, 133, 2812-2819. https://doi.org/10.1093/jn/133.9.2812

[12] Stratil, P., Klejdus, B. and Kuban, V. (2006) Determination of Total Content of Phenolic Compounds and Their Antioxidant Activity in Vegetables: Evaluation of Spectrophotometric Methods. Journal of Agricultural and Food Chemistry, 54, 607-616. https://doi.org/10.1021/jf052334j

[13] Melo, E.D.A., Lima, V.L.A.G., Maciel, M.I.S., Caetano, A.C.S. and Leal, F.L.L. (2006) Polyphenol, Ascorbic Acid and Total Carotenoid Contents in Common Fruits and Vegetables. Brazilian Journal of Food Technology, 9, 89-94.

[14] Chu, Y.-F., Sun, J., Wu, X. and Liu, R.H. (2002) Antioxidant and Antiproliferative Activities of Common Vegetables. Journal of Agricultural and Food Chemistry, 50, 6910-6916. https://doi.org/10.1021/jf020665f

[15] Chandrasekar, B., Mukherjee, B. and Mukherjee, S.K. (1989) Blood Sugar Lowering Potentiality of Selected Cucurbitaceae Plants of Indian Origin. Indian Journal of Medical Research, 90, 300-305.

[16] Roman-Ramos, R., Flores-Saenz, J.L. and Alarcon-Aguilar, F.J. (1995) Anti-Hyperglycemic Effect of Some Edible Plants. Journal of Ethnopharmacology, 48, 25-32. https://doi.org/10.1016/0378-8741(95)01279-M

[17] Sudheesh, S. and Vijayalakshmi, N.R. (1999) Lipid-Lowering Action of Pectin from Cucumis sativus. Food Chemistry, 67, 281-286. https://doi.org/10.1016/S0308-8146(99)00135-1

[18] Allen, A.K. (1979) A Lectin from the Exudate of the Fruit of the Vegetable Marrow (Cucurbita pepo) That Has a Specificity for Beta-1,4-linked N-Acetylglucosamine Oligosaccharides. Biochemical Journal, 183, 133-137. https://doi.org/10.1042/bj1830133

[19] Warrier, P.K. (1994) Indian Medicinal Plants: A Compendium of 500 Species. Press Orientlongman, Chennai.

[20] Gill, N.S., Garg, M., Bansal, R., Sood, S., Muthuraman, A., Bali, M., et al. (2009) Evaluation of Antioxidant and Antiulcer Potential of Cucumis sativus L. Seed Extract in Rats. Asian Journal of Clinical Nutrition, 1, 131-138. https://doi.org/10.3923/ajcn.2009.131.138

[21] Jain, K., Kataria, S. and Guruprasad, K.N. (2004) Effect of UV-B Radiation on Antioxidant Enzymes and Its Modulation by Benzoquinone and a-Tocopherol in $\mathrm{Cu}$ cumber Cotyledons. Current Science, 87, 87-90.

[22] Mukherjee, P.K., Nema, N.K., Maity, N. and Sarkar, B.K. (2013) Phytochemical and Therapeutic Potential of Cucumber. Fitoterapia, 84, 227-236.

https://doi.org/10.1016/j.fitote.2012.10.003 